\title{
How does the oxidation state of palladium surfaces affect the reactivity and selectivity of direct synthesis of hydrogen peroxide from hydrogen and oxygen gases? A density functional study
}

DOI:

10.1021/jacs.8b10281

Document Version

Accepted author manuscript

Link to publication record in Manchester Research Explorer

Citation for published version (APA):

Wang, F., Xia, C., De Visser, S., \& Wang, Y. (2018). How does the oxidation state of palladium surfaces affect the reactivity and selectivity of direct synthesis of hydrogen peroxide from hydrogen and oxygen gases? A density functional study. Journal of the American Chemical Society. https://doi.org/10.1021/jacs.8b10281

\section{Published in:}

Journal of the American Chemical Society

\section{Citing this paper}

Please note that where the full-text provided on Manchester Research Explorer is the Author Accepted Manuscript or Proof version this may differ from the final Published version. If citing, it is advised that you check and use the publisher's definitive version.

\section{General rights}

Copyright and moral rights for the publications made accessible in the Research Explorer are retained by the authors and/or other copyright owners and it is a condition of accessing publications that users recognise and abide by the legal requirements associated with these rights.

\section{Takedown policy}

If you believe that this document breaches copyright please refer to the University of Manchester's Takedown Procedures [http://man.ac.uk/04Y6Bo] or contact uml.scholarlycommunications@manchester.ac.uk providing relevant details, so we can investigate your claim.

\section{OPEN ACCESS}




\title{
How does the oxidation state of palladium surfaces affect the reactivity and selectivity of direct synthesis of hydrogen peroxide from hydrogen and oxygen gases? A density functional study
}

\author{
Fang Wang, ${ }^{\dagger}$ Chungu Xia, ${ }^{\dagger}$ Sam P. de Visser ${ }^{*, \neq}$ and Yong Wang ${ }^{*,+\S}$ \\ ${ }^{\dagger}$ State Key Laboratory for Oxo Synthesis and Selective Oxidation, Suzhou Research Institute of LICP, Lanzhou \\ Institute of Chemical Physics (LICP), Chinese Academy of Sciences, Lanzhou, 730ooo, P. R. China \\ ${ }^{*}$ Manchester Institute of Biotechnology and School of Chemical Engineering and Analytical Science, The University \\ of Manchester, 131 Princess Street, Manchester M1 7DN, United Kingdom \\ ${ }^{\S}$ Institute of Drug Discovery Technology, Ningbo University, Ningbo 315211, P. R. China
}

\begin{abstract}
Direct synthesis of $\mathrm{H}_{2} \mathrm{O}_{2}$ from $\mathrm{H}_{2}$ and $\mathrm{O}_{2}$ is an environmentally benign and atom economic process and as such is the ideal pathway in catalysis. However, currently no low-cost pathway of this kind of catalysis exists although it would be an attractive alternative strategy to the common industrial anthraquinone method for $\mathrm{H}_{2} \mathrm{O}_{2}$ production. Metal-based catalysts are widely employed in such direct synthesis process, but often need to be oxidized, alloyed or supplied with additives to make them selective. To understand the metal-oxidation state in heterogeneous catalysis, we studied the selective oxidation of hydrogen by molecular oxygen on a $\mathrm{Pd}(111)$ and $\mathrm{PdO}(101)$ surface leading to either $\mathrm{H}_{2} \mathrm{O}_{2}$ or $\mathrm{H}_{2} \mathrm{O}$ products. Our results demonstrate, for the first time, that the oxidized $\mathrm{PdO}(101)$ surface clearly shows better performance and selectivity, as compared to the reduced $\mathrm{Pd}(111)$ one. The activation barrier on the oxidized Pd surface is ca. $0.2 \mathrm{eV}$ lower than the one on the reduced Pd surface. On the oxidized surface, the $\mathrm{H}_{2} \mathrm{O}_{2}$ synthesis route is preferred while on the reduced surface the $\mathrm{H}_{2} \mathrm{O}$ route is predominant. The decomposition of $\mathrm{H}_{2} \mathrm{O}_{2}$ is also greatly inhibited on the oxidized surface. We analyzed the different pathways in detail through thermochemical cycles, which establishes that the oxidized surface shows weaker adsorption ability toward the reagents $\mathrm{O}_{2}$ and $\mathrm{H}_{2}$, the key intermediate $\mathrm{OOH}$ and also the product $\mathrm{H}_{2} \mathrm{O}_{2}$ in comparison with the $\mathrm{Pd}(111)$ surface, which we believe affect the selectivity. The work presented here clearly shows that the oxidation state of metal surfaces is one of the most important factors that tunes the catalysis of a chemical reaction and can affect the selectivity and reaction patterns dramatically.
\end{abstract}

\section{Introduction}

Hydrogen peroxide $\left(\mathrm{H}_{2} \mathrm{O}_{2}\right)$ is an environmentally benign oxidant due to its green nature that generates harmless $\mathrm{H}_{2} \mathrm{O}$ as the only by-product of an oxygenation reaction. Current use of hydrogen peroxide is not only extensive in the textile industry, but also in pulp and paper manufacture, food, aquaculture, water and wastewater treatment processes, etc. ${ }^{1}$ Because of the explosive growth in its utilization over the last three decades, the demand for hydrogen peroxide has increased by $>5 \%$ per year and is expecting to grow further at this rate until 2023. ${ }^{2}$ Currently, most of the $\mathrm{H}_{2} \mathrm{O}_{2}$ is produced through the indirect anthraquinone auto-oxidation process developed by Riedl and Pfleiderer. ${ }^{3}$ Although this method has the advantages of avoiding direct mixture of $\mathrm{H}_{2}$ and $\mathrm{O}_{2}$ and as such is suitable for large-scale and continuous operation, it also has several drawbacks. In particular, the yield encounters complex separation and concentration steps, and economic issues. ${ }^{4}$
Scheme 1. Main reactions and side-reactions involved in the direct synthesis of $\mathrm{H}_{2} \mathrm{O}_{2}$ from $\mathrm{H}_{2}$ and $\mathrm{O}_{2}$. Process labeled with red color denotes the desirable main reactions.

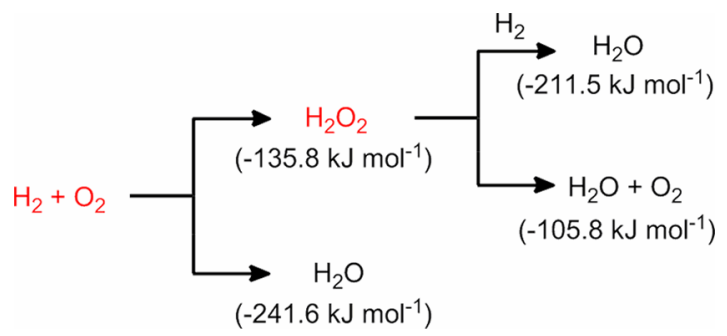

The direct synthesis of $\mathrm{H}_{2} \mathrm{O}_{2}$ from $\mathrm{O}_{2}$ and $\mathrm{H}_{2}$, however, is seen as an attractive alternative to the anthraquinone auto-oxidation process and has been extensively studied in recent years. ${ }^{4-13}$ Unfortunately, as shown in Scheme 1, the formation of $\mathrm{H}_{2} \mathrm{O}_{2}$ directly from $\mathrm{H}_{2}$ and $\mathrm{O}_{2}$ is thermochemically less favorable by $105.8 \mathrm{~kJ} \mathrm{~mol}^{-1}$ than the formation of $\mathrm{H}_{2} \mathrm{O}$ from reactants. ${ }^{4}$ In addition, $\mathrm{H}_{2} \mathrm{O}_{2}$ is 
very reactive, and is easy to hydrogenate or decompose into water. Both of these results indicate that the direct synthesis of $\mathrm{H}_{2} \mathrm{O}_{2}$ from $\mathrm{H}_{2}$ and $\mathrm{O}_{2}$ is a challenging process. Thus, an effective catalyst with high selectivity toward $\mathrm{H}_{2} \mathrm{O}_{2}$ formation that simultaneously prevents product degradation is highly desirable in the Chemical Industry. ${ }^{13}$

Up to now, many catalysts have been developed for the direct synthesis of $\mathrm{H}_{2} \mathrm{O}_{2}{ }^{6,7}$ Often these surface catalysts need to be oxidized or doped in order to stimulate and trigger the reaction. Why and how this is needed remains uncertain and controversial. Supported palladium surfaces are the most-used catalysts since the direct synthesis of $\mathrm{H}_{2} \mathrm{O}_{2}$ from $\mathrm{H}_{2}$ and $\mathrm{O}_{2}$ was first reported in 1914. ${ }^{14}$ However, $\mathrm{Pd}$ catalysts not only have high activity toward the synthesis of $\mathrm{H}_{2} \mathrm{O}_{2}$, but also show a large amount of its hydrogenation and decomposition; therefore, the selectivity of $\mathrm{Pd}$ toward $\mathrm{H}_{2} \mathrm{O}_{2}$ formation is very low. Consequently, a number of methods have been developed to overcome the low $\mathrm{H}_{2} \mathrm{O}_{2}$ selectivity issue of Pd catalyst. The addition of halides $\left(\mathrm{X}^{-}\right)$and mineral acids is taken as an effective method to improve the $\mathrm{H}_{2} \mathrm{O}_{2}$ selectivity. ${ }^{15-19}$ This was rationalized from adsorption of $\mathrm{X}^{-}$ and $\mathrm{H}^{+}$pairs on the sites responsible for the undesired by-products and thereby suppressing the generation of $\mathrm{H}_{2} \mathrm{O}$ and enhancing the selectivity toward $\mathrm{H}_{2} \mathrm{O}_{2}$ formation. $^{20}$ However, the presence of halides and mineral acids can also facilitate metal leaching and requires to be separated from the product after reaction. ${ }^{21}$ Another and even more effective method is the use of bimetallic catalysts, where the addition of the second metal improves $\mathrm{H}_{2} \mathrm{O}_{2}$ selectivity. ${ }^{22} \mathrm{PdAu}$ alloy catalysts supported on an acid pretreated carbon material $(\mathrm{PdAu} / \mathrm{C})$ were shown to effectively inhibit $\mathrm{H}_{2} \mathrm{O}_{2}$ hydrogenation thereby leading to improved yields of $\mathrm{H}_{2} \mathrm{O}_{2}$. However, the high $\mathrm{PdAu}$ activity was unable to fully reproduce on commercial support materials such as $\mathrm{SiO}_{2}$ and $\mathrm{TiO}_{2}$, and hence no industrial applications of the $\mathrm{PdAu} / \mathrm{C}$ catalysts are known.

Recently, a PdSn bimetallic catalyst supported on $\mathrm{TiO}_{2}$ or $\mathrm{SiO}_{2}$ was found to achieve very high selectivity toward $\mathrm{H}_{2} \mathrm{O}_{2}(>95 \%)$ formation after an appropriate oxidationreduction-oxidation heat treatment process. ${ }^{7}$ This catalyst was found to be more economic than PdAu. Moreover, it is not necessary to pretreat the supports by acids and no additives ( $\mathrm{X}^{-}$and acids) were required to be added to carry the industrialization of the direct synthesis of $\mathrm{H}_{2} \mathrm{O}_{2}$ forward. A detailed characterization by X-ray photoelectron spectroscopy (XPS) demonstrated that $\mathrm{Pd}^{2+}$ was the predominant surface species. Once these $\mathrm{Pd}-\mathrm{Sn}$ catalysts were reduced, the high selectivity toward $\mathrm{H}_{2} \mathrm{O}_{2}$ was lost, which was ascribed to the reduction of $\mathrm{Pd}^{2+}$ into metallic $\mathrm{Pd}^{\mathrm{o}}$ - a well-known effective $\mathrm{H}_{2} \mathrm{O}_{2}$ degradation catalyst. ${ }^{23}$ These results indicate the oxidation state of $\mathrm{Pd}$ plays important roles for the selective formation of $\mathrm{H}_{2} \mathrm{O}_{2}$.

For the above-mentioned bimetallic $\mathrm{PdAu} / \mathrm{C}$ catalyst, a further detailed characterization using XPS and aberration-corrected scanning transmission electron microscopy indicated that the majority of $\mathrm{Pd}$ is present as $\mathrm{Pd}^{2+}$ for the acid pretreated $\mathrm{PdAu} / \mathrm{C}$ catalysts. ${ }^{23}$ However, metallic $\mathrm{Pd}$ increases for the catalyst without acid pretreatment. The high $\mathrm{H}_{2} \mathrm{O}_{2}$ productivity and low $\mathrm{H}_{2} \mathrm{O}_{2}$ hydrogenation activity is only observed with the acid pretreated $\mathrm{PdAu} / \mathrm{C}$, suggesting the catalyst activity is associated with the oxidation state of Pd. In fact, several other groups have also proposed that oxidized palladium could play a more important role than $\mathrm{Pd}^{\mathrm{o}}$ toward the selective generation of $\mathrm{H}_{2} \mathrm{O}_{2} \cdot{ }^{24-30}$ However, it is still unclear what role the oxidized palladium plays during the generation of $\mathrm{H}_{2} \mathrm{O}_{2}$. For instance, what is the difference in adsorption and fragmentation of $\mathrm{O}_{2}$ and $\mathrm{H}_{2}$ on the oxidized $\mathrm{Pd}$ surface in comparison with metallic $\mathrm{Pd}$ ? What determines the activity of oxidized $\mathrm{Pd}$ toward the formation and the degradation of $\mathrm{H}_{2} \mathrm{O}_{2}$ ? These challenging topics are pivotal for understanding the active sites and formation mechanism for the direct synthesis of $\mathrm{H}_{2} \mathrm{O}_{2}$. If resolved, it will promote the design of more effective catalysts.

Current computational and mechanistic studies so far have mainly focused on the formation and degradation of $\mathrm{H}_{2} \mathrm{O}_{2}$ on $\mathrm{Pd}, \mathrm{Au}$, or $\mathrm{PdAu}$ clusters, monometallic $\mathrm{Pd}$ surfaces, and bimetallic PdAu, PdAg surfaces. ${ }^{20,31-43}$ Flaherty and coworkers found the formation of $\mathrm{H}_{2} \mathrm{O}_{2}$ follow proton-electron transfer mechanisms. ${ }^{9}$ No theoretical studies have been reported on the oxidized palladium with respect to its production of $\mathrm{H}_{2} \mathrm{O}_{2}$. In this work we present a detailed periodic density functional theory study on the various pathways of $\mathrm{H}_{2}$ and $\mathrm{O}_{2}$ adsorption and dissociation on metallic $\mathrm{Pd}$ and $\mathrm{PdO}$ surfaces as well as the subsequent steps leading to $\mathrm{H}_{2} \mathrm{O}_{2}$ and $\mathrm{H}_{2} \mathrm{O}$ products and the decomposition of $\mathrm{H}_{2} \mathrm{O}_{2}$. In addition, a thermochemical and electronic analysis of the reaction mechanisms have been performed, which highlights the origins of the reactivity differences of $\mathrm{PdO}$ vs Pd. Our work ultimately leads to predictions on how to develop catalysts for efficient synthesis of $\mathrm{H}_{2} \mathrm{O}_{2}$.

\section{Computational Methodology}

2.1 Surface models. For polycrystalline Pd, (111) and (100) planes are the principally exposed surfaces. Many experimental studies found that the formation of $\mathrm{PdO}(101)$ is preferred during the oxidation of $\operatorname{Pd}(111)$ and $\operatorname{Pd}(100)$ surfaces by means of in situ investigations. ${ }^{44}$ Moreover, DFT studies showed that $\mathrm{PdO}(101)$ is a stable low-index surface. ${ }^{45}$ The direct synthesis of $\mathrm{H}_{2} \mathrm{O}_{2}$ is usually carried out with excess $\mathrm{O}_{2}{ }^{6,7}$ Hence, it is reasonable to choose $\mathrm{PdO}(101)$ as the model of the oxidized Pd catalyst in this work. ${ }^{45}$ The $\mathrm{PdO}(101)$ surface has half of the atoms
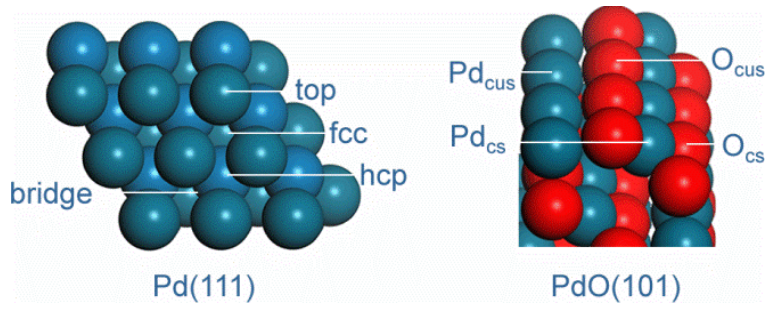

Figure 1. $\operatorname{Pd}(111)$ and $\operatorname{Pd}(101)$ surfaces. The top, bridge, fcc, and hcp site for $\mathrm{Pd}(111)$, and the $\mathrm{O}_{\text {cus }}$ and $\mathrm{Pd}_{\text {cus }}$ atoms and coordinatively saturated (cs) O and Pd atoms were labeled. 
coordinatively unsaturated (cus) on the $\mathrm{O}$ and $\mathrm{Pd}$ atoms (Figure 1), which may be important in oxidation reactions. As above-mentioned, $\operatorname{Pd}(111)$ surface is one of the low-index surface of metallic Pd. Our calculations focus on $\mathrm{Pd}(111)$ and $\mathrm{PdO}(101)$ surfaces only here.

2.2 Computational details. The periodic DFT slab calculations for $\mathrm{H}_{2} \mathrm{O}_{2}$ formation on $\mathrm{Pd}(111)$ and $\mathrm{PdO}(101)$ surfaces were carried out employing the ultrasoft pseudopotentials ${ }^{46}$ and the spin polarized generalized gradient approximation (GGA) exchange-correlation functional proposed by Perdew, Burke, and Ernzerhof (PBE) ${ }^{47}$ as implemented in CASTEP suite of programs. ${ }^{48}$ For the optimization of $\mathrm{H}_{2}, \mathrm{Pd}(111)$ surface, and $\mathrm{H}_{2}$ adsorption on the $\mathrm{Pd}(111)$ surface, only the spin unpolarized functional was employed. The geometry optimizations were performed with fine accuracy. An energy cutoff of $340 \mathrm{eV}$ and $400 \mathrm{eV}$ was applied for the plane-wave expansion of the electronic eigenfunctions of the $\mathrm{Pd}(111)$ and $\mathrm{PdO}(101)$ surfaces, respectively. The adopted energy cutoffs for $\mathrm{Pd}(111)$ and $\mathrm{PdO}(101)$ used here have been extensively tested and validated on analogous systems. ${ }^{33,34,49,50}$ Convergence benchmark test calculations were performed for the energy cutoff of the $\mathrm{PdO}(101)$ surface (Table Si Supporting Information), which confirms our selection of $E_{\text {cut }}=400 \mathrm{eV}$ is proper. Recent studies comparing the combined pure DFT and the DFT with Hubbard $U$ correction (DFT $+U$ ) procedures on the $\mathrm{C}-\mathrm{H}$ bond activation of $\mathrm{CH}_{4}$ on a $\mathrm{PdO}(101)$ and $\mathrm{PdO}(100)$ surface showed that the accuracy of the calculations was affected little by the Hubbard $U$ correction factor. ${ }^{51}$ Therefore, all calculations were carried out by employing standard DFT methods.

The surface Brillouin zone was sampled with a $3 \times 3 \times 1$ Monkhorst-Pack k-point grid for Pd(111), a $4 \times 2 \times 1$ grid for $\mathrm{PdO}(101)$, and a gamma point for $\mathrm{O}_{2}$ and $\mathrm{H}_{2}$ optimization. The $\mathrm{Pd}(111)$ and $\mathrm{PdO}(101)$ surfaces were modeled with a periodic four-layer slab with $3 \times 3$ and $4 \times$ 1 unit cells, respectively. In the current work, one $\mathrm{O}-2 \mathrm{Pd}-\mathrm{O}$ tri-layer of $\mathrm{PdO}$ is defined as a monolayer. Previous studies showed that these thicknesses are sufficient to accurately model the experimental $\mathrm{Pd}(111)$ and $\mathrm{PdO}(101)$ surfaces. ${ }^{49}$ The periodically repeated slabs were separated with a vacuum thickness of $10 \AA$ for $\mathrm{Pd}(111)$ and $20 \AA$ for $\mathrm{PdO}(101)$ in order to avoid the neighboring slab interactions along z-axis. The convergence criteria for geometry optimization were set to 0.03 (for the local minima) and 0.05 (for transition states) $\mathrm{eV} \AA^{-1}$ for maximum force, $1.0 \times 10^{-5} \mathrm{eV}$ atom ${ }^{-1}$ for energy, $1.0 \times 10^{-6}$ $\mathrm{eV}$ atom $^{-1}$ for the SCF, and o.oor $\AA$ for maximum displacement. The top two (three) layers for Pd (PdO) were fully relaxed whereas the bottom two (one) layers were fixed at the corresponding bulk positions. The linear and quadratic synchronous transit (LST/QST) complete search method was employed to identify the transition states. A Bader charge analysis was performed using the code developed by Henkelman and co-workers., ${ }^{52,53}$ If there was no special statement, the discussion was based on Mulliken charge analysis. The lattice constant for bulk Pd was predicted to be $3.93 \AA$, and $\mathrm{a}=\mathrm{b}=3.11 \AA \AA$ and $\mathrm{c}=$
$5.44 \AA$ for PdO, respectively, which is in good agreement with the experimental values of $3.89 \AA^{54}$ and $\mathrm{a}=\mathrm{b}=3.04 \AA$, $c=5.34 \AA . .^{.55}$

The adsorption energy $\left(E_{a d s}\right)$ of $X_{2}, X_{2}=H_{2}$ or $\mathrm{O}_{2}$, on the $\mathrm{Pd}(111)$ and $\mathrm{PdO}(101)$ surfaces is defined as in Eq 1 with $\mathrm{E}\left(\mathrm{slab}-\mathrm{X}_{2}\right)$ the bound complex and $\mathrm{E}\left(\mathrm{X}_{2}\right)$ and $\mathrm{E}(\mathrm{slab})$ the isolated $\mathrm{X}_{2}$ and slab energies, respectively.

$$
\mathrm{E}_{\mathrm{ads}}=\mathrm{E}\left(\mathrm{slab}-\mathrm{X}_{2}\right)-\left[\mathrm{E}\left(\mathrm{X}_{2}\right)+\mathrm{E}(\text { slab })\right]
$$

The d-band center was calculated as the first moment of the projected d-band density of states on the surface atoms relative to the Fermi level.

\section{Results}

3.1 $\mathrm{O}_{2}$ and $\mathrm{H}_{2}$ adsorption and dissociation. For the direct synthesis of $\mathrm{H}_{2} \mathrm{O}_{2}$, the active forms of $\mathrm{O}_{2}$ and $\mathrm{H}_{2}$ on surfaces are the first key problem to be considered. Previous isotope labeling experiments have confirmed that the generation of $\mathrm{H}_{2} \mathrm{O}_{2}$ is derived from molecular oxygen rather than from the dissociated atomic oxygen..$^{56}$ Once $\mathrm{O}_{2}$ dissociates, it mainly leads to the production of side-product $\mathrm{H}_{2} \mathrm{O}$, which is not desirable for the synthesis of $\mathrm{H}_{2} \mathrm{O}_{2}$. As such, the dissociation of $\mathrm{O}_{2}$ is one of the pivotal factors controlling the selectivity of the $\mathrm{H}_{2} \mathrm{O}_{2}$

(a) the adsorption of $\mathrm{O}_{2}$

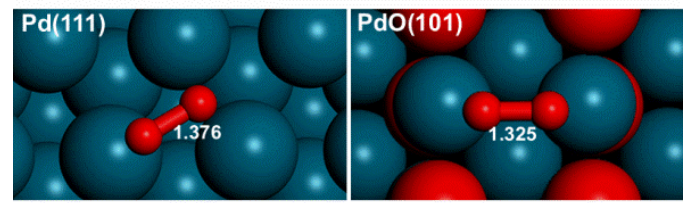

(b) the dissociation of $\mathrm{O}_{2}$

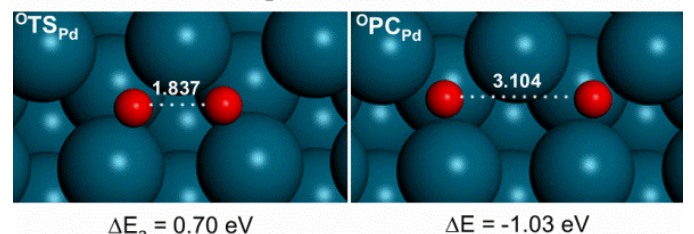

(c) the adsorption of $\mathrm{H}_{2}$

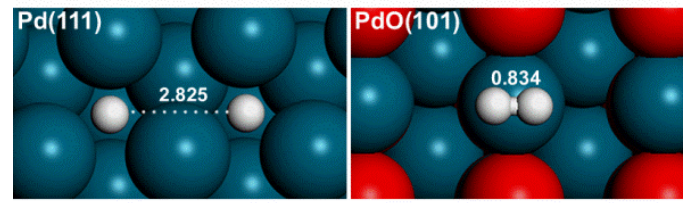

(d) the dissociation of $\mathrm{H}_{2}$

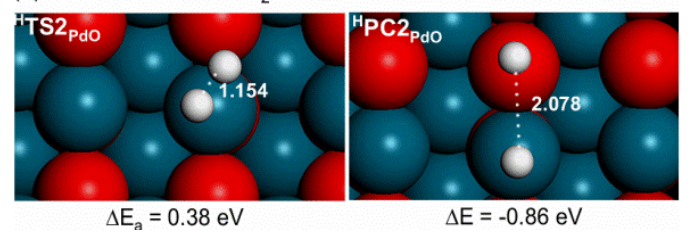

Figure 2. $\mathrm{O}_{2}$ and $\mathrm{H}_{2}$ adsorption and dissociation on $\mathrm{Pd}(111)$ and $\mathrm{PdO}(101)$ surfaces with bond distances in angstroms and energies in eV. (a) The most favorable $\mathrm{O}_{2}$ adsorption geometries; (b) The dissociation of $\mathrm{O}_{2}$ on $\mathrm{Pd}(111)$ surfaces; (c) The most favorable $\mathrm{H}_{2}$ adsorption geometries; (d) The dissociation of $\mathrm{H}_{2}$ on a $\mathrm{PdO}(101)$ surfaces. 
production at the initial stage. On the other hand, $\mathrm{H}_{2}$ dissociation is essential for the formation of $\mathrm{H}_{2} \mathrm{O}_{2}$.

Our initial studies focused on the adsorption and dissociation of $\mathrm{O}_{2}$ and $\mathrm{H}_{2}$ on the $\mathrm{Pd}(111)$ and $\mathrm{PdO}(101)$ surfaces and the results are given in Figure 2. We tested many possible binding orientations, see Tables $\mathrm{S}_{2}$ and $\mathrm{S}_{3}$ (Supporting Information), but will only report the lowest in energy here. Thus, the most favorable adsorption of $\mathrm{O}_{2}$ on $\operatorname{Pd}(111)$ is in a top-bridge configuration with one oxygen atom at the top site of Pd and the second one lying in a gap between two Pd atoms. The adsorption energy is estimated to be $-1.16 \mathrm{eV}$. Binding of $\mathrm{O}_{2}$ leads to elongation of the $\mathrm{O}-\mathrm{O}$ bond distance to $1.376 \AA$ as compared to the free molecule that has a distance of 1.238 $\AA$. These distances in the bound form match metal-superoxo bond lengths calculated previously and implies that $\mathrm{O}_{2}$ is highly activated after its adsorption on $\operatorname{Pd}(111)$ and binds as a Pd-superoxo. ${ }^{57,58} \mathrm{~A}$ Mulliken analysis demonstrates that -0.40 e is transferred to $\mathrm{O}_{2}$ from $\operatorname{Pd}(111)$, which further confirms $\mathrm{O}_{2}$ is highly activated.

Dioxygen dissociation on the $\operatorname{Pd}(111)$ surface gives an $\mathrm{O}-\mathrm{O}$ interaction at $1.837 \AA$ in the transition state (see Figure 2b) with a barrier of $0.70 \mathrm{eV}$. Previous studies reported a barrier of $0.67 \mathrm{eV}, 0.77 \mathrm{eV}$, and $0.75 \mathrm{eV}, 34,59,60$ therefore our result matches the literature well. The $\mathrm{O}_{2}$ dissociation on a $\mathrm{Pd}(111)$ surface is exothermic by $-1.03 \mathrm{eV}$ thereby confirming the feasibility of $\mathrm{O}_{2}$ dissociation on the $\operatorname{Pd}(111)$ surface.

On $\mathrm{PdO}(101)$ surfaces, we investigated $\mathrm{O}_{2}$ adsorption on $\mathrm{Pd}_{\text {cus }}$ and $\mathrm{Pd}_{\mathrm{cs}}$, respectively. However, the most favorable adsorption of $\mathrm{O}_{2}$ is on the bridge $\mathrm{Pd}_{\text {cus }}$ sites along the $\mathrm{Pd}$ row with an adsorption energy of $-1.25 \mathrm{eV}$, which is 0.09 $\mathrm{eV}$ higher than that found on the $\mathrm{Pd}(111)$ surface. It appears, therefore, that the adsorption of $\mathrm{O}_{2}$ on $\mathrm{PdO}(101)$ surface is a little stronger than that on the $\mathrm{Pd}(111)$ surface. However, a short O-O distance of $1.325 \AA$ was obtained. The charge distribution gives a total charge on $\mathrm{O}_{2}$ of -0.26 e, which is 0.14 e less than the $\mathrm{O}_{2}$ bound complex on $\operatorname{Pd}(111)$. These results suggest that $\mathrm{O}_{2}$ is less activated on $\mathrm{PdO}(101)$ than on $\mathrm{Pd}(111)$. Additionally, the Bader charge of adsorbed $\mathrm{O}_{2}$ is 0.43 e, which implicates that the adsorbed $\mathrm{O}_{2}$ is in a superoxo-like state.

Subsequently, the dissociation of $\mathrm{O}_{2}$ on the $\mathrm{PdO}(101)$ surface was studied. The dissociation of $\mathrm{O}_{2}$ on $\mathrm{PdO}(101)$ is a high energy process that is endothermic by $1.81 \mathrm{eV}$ and no $\mathrm{O}_{2}$ dissociation barrier could be calculated. Our calculations imply that the dissociative adsorption of $\mathrm{O}_{2}$ on $\operatorname{Pd}(101)$ is not favorable, which is consistent with previous experimental findings as well as DFT studies. ${ }^{61}$

In the case of $\mathrm{H}_{2}$ adsorption, the calculated results indicate that $\mathrm{H}_{2}$ prefers dissociative adsorption on $\mathrm{Pd}(111)$ with a binding energy of $-1.39 \mathrm{eV}$ (Figure 2c), in agreement with previous reports about the spontaneous hydrogen dissociation. ${ }^{43}$ By contrast, $\mathrm{H}_{2}$ is adsorbed in molecular form on the top site of $\mathrm{Pd}_{\text {cus }}$ in $\mathrm{PdO}(101)$ surface with an energy of $-0.53 \mathrm{eV}$ (Figure $2 \mathrm{c}$, right panel, and Table $\left.\mathrm{S}_{3}\right) . \mathrm{H}_{2}$ lies parallel along the $\mathrm{Pd}_{\text {cus }}$ row with a $\mathrm{H}-\mathrm{H}$ distance of $0.834 \AA$ A. Both the adsorption energy and $\mathrm{H}-\mathrm{H}$ distance indicate the adsorption of $\mathrm{H}_{2}$ on $\mathrm{PdO}(101)$ surface is much weaker than that on $\operatorname{Pd}(111)$. Starting with the mentioned favorable adsorption configuration as the reaction entrance (denoted as path $\mathrm{I}$ ), we investigated $\mathrm{H}_{2}$ dissociation on the $\mathrm{PdO}(101)$ surface and located a transition state $\left({ }^{\mathrm{H}} \mathbf{T S} \mathbf{1}_{\mathrm{PdO}}\right)$, with its geometry shown in Figure $\mathrm{S}_{3}$. The corresponding barrier and reaction energy are $0.33 \mathrm{eV}$ and $0.23 \mathrm{eV}$, respectively. The endothermic nature of the dissociation along this pathway implies that the molecularly adsorption is more preferable.

Subsequently, we tested whether the dissociated $\mathrm{H}$ atoms can directly migrate to the top site of the $\mathrm{O}_{\text {cus }}$ atoms. We find this $\mathrm{H}$ atom migration process requires an energetic barrier of $0.68 \mathrm{eV}$ with a reaction energy of -1.10 $\mathrm{eV}$. In addition, the alternative dissociation pathway was investigated for comparison (denoted as path II, Figure 2d). This process starts with the adsorption of $\mathrm{H}_{2}$ perpendicular to the Pd rows which is $0.08 \mathrm{eV}$ higher in energy than the parallel adsorption one. However, the $\mathrm{H}_{2}$ dissociation pathway occurs through the elongation of the $\mathrm{H}-\mathrm{H}$ bond where one $\mathrm{H}$ atom is kept on the top of the $\mathrm{Pd}_{\text {cus }}$ site, while the other one transfers to the neighboring oxygen atom. The energy barrier for this process is 0.38 $\mathrm{eV}$, which is comparable with the one for path I. On the other hand, the reaction energy is exothermic with -0.86 $\mathrm{eV}$, indicating that the dissociation of $\mathrm{H}_{2}$ along this pathway is thermodynamically favorable.

3.2 Formation Mechanism of $\mathbf{H}_{2} \mathrm{O}_{2}$. Based on the results of $\mathrm{H}_{2}$ and $\mathrm{O}_{2}$ adsorption and dissociation, we studied the reaction of $\mathrm{H}_{2}$ with $\mathrm{O}_{2}$ on $\mathrm{Pd}(111)$ and $\mathrm{PdO}(101)$ surfaces. Previous work on the hydroperoxy $(\mathrm{OOH})$ species identified it as a key intermediate during the vapor-phase reaction of $\mathrm{H}_{2}$ and $\mathrm{O}_{2}$ on $\mathrm{Au} / \mathrm{TiO}_{2}$ employing inelastic neutron scattering spectroscopy. ${ }^{62}$ Therefore, the $\mathrm{OOH}$ species is generally proposed to be the key intermediate for the synthesis of $\mathrm{H}_{2} \mathrm{O}_{2}$. Here, the hydrogenation of $\mathrm{O}_{2}$ to generate the $\mathrm{OOH}$ species is taken as the first reaction step. As such, the hydrogenation of $\mathrm{OOH}$ may lead to the production of $\mathrm{H}_{2} \mathrm{O}_{2}$ (denoted as $\mathrm{H}_{2} \mathrm{O}_{2}$ channel). All the processes with respect to the breaking of the $\mathrm{O}-\mathrm{O}$ bond are acknowledged as the main factors that control the selectivity of the direct synthesis process, for instance, $\mathrm{OOH}$ and $\mathrm{H}_{2} \mathrm{O}_{2}$ decomposition. ${ }^{34,41}$ Therefore, to inspect the $\mathrm{H}_{2} \mathrm{O}_{2}$ selectivity issues, the dissociation of $\mathrm{OOH}$ by $\mathrm{O}-\mathrm{O}$ bond cleavage resulting in the formation of $\mathrm{H}_{2} \mathrm{O}$ (denoted as $\mathrm{H}_{2} \mathrm{O}$ channel) and the decomposition of $\mathrm{H}_{2} \mathrm{O}_{2}$ were both calculated.

3.2.1 Reactivity on the Pd(111) surface. As can be seen in Figure 3, adsorbed $\mathrm{O}_{2}$ reacts with an adsorbed hydrogen atom at the start of the reaction resulting in the formation of an $\mathrm{OOH}$ species. The energetic barrier (TS1) is estimated to be $0.68 \mathrm{eV}$, which is comparable with the $\mathrm{O}_{2}$ dissociation of $0.70 \mathrm{eV}$. As such, the formation of the $\mathrm{OOH}$ species and the dissociation of $\mathrm{O}_{2}$ are competitive processes on the $\mathrm{Pd}(111)$ surface. Consequently, the selectivity toward the generation of $\mathrm{H}_{2} \mathrm{O}_{2}$ will be low. On the other hand, since the $\mathrm{OOH}$ species can be formed, it 

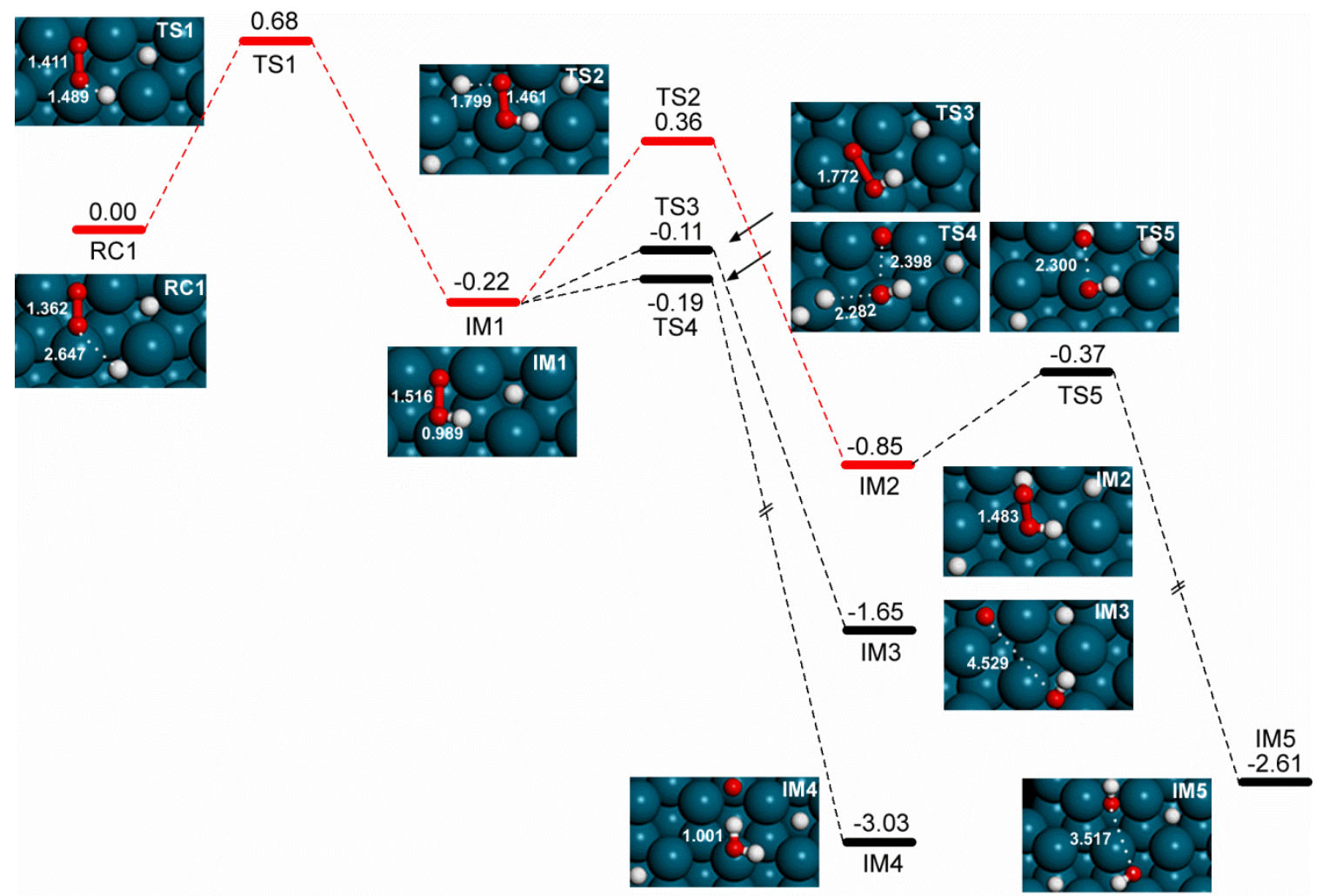

Figure 3. The energy profiles for the reaction of $\mathrm{O}_{2}$ with $\mathrm{H}_{2}$ on $\mathrm{Pd}(111)$ surface. The formation of $\mathrm{H}_{2} \mathrm{O}_{2}$ is labeled by red color. The energies are in $\mathrm{eV}$ unit.

may subsequently abstract another $\mathrm{H}$ atom to generate the main product $\mathrm{H}_{2} \mathrm{O}_{2}$ via TS2 or alternatively lead to the breaking of the $\mathrm{O}-\mathrm{O}$ bond via $\mathrm{TS}_{3}$ and yield a hydroxyl species and atomic oxygen. The barriers of these two steps are estimated to be $0.58 \mathrm{eV}\left(\mathbf{T S}_{\mathbf{2}}\right)$ and $0.11 \mathrm{eV}\left(\mathbf{T S}_{\mathbf{3}}\right)$, respectively. If atomic hydrogen is present in the vicinity of the $\mathrm{OOH}$ species, it will assist the dissociation of the $\mathrm{OOH}$ species and lead to the formation of water by one concerted step (via $\mathbf{T S}_{\mathbf{4}}$ in Figure 3 ) with a barrier of only $0.03 \mathrm{eV}$. With these results in mind, after the formation of the $\mathrm{OOH}$ species, the most favorable step refers to the concerted dissociation of $\mathrm{OOH}$ and simultaneously formation of water rather than the formation of $\mathrm{H}_{2} \mathrm{O}_{2}$. Once $\mathrm{H}_{2} \mathrm{O}_{2}$ forms, it easily dissociates into two hydroxyl radicals with a barrier (TS5) of $0.48 \mathrm{eV}$. The present results indicate that the minimum energy pathway for the reaction of $\mathrm{H}_{2}$ and $\mathrm{O}_{2}$ on a $\mathrm{Pd}(111)$ surface leads to the dissociation of $\mathrm{OOH}$ and the formation of side product $\mathrm{H}_{2} \mathrm{O}$. Consequently, the calculations predict little or no formation of $\mathrm{H}_{2} \mathrm{O}_{2}$ on a pure $\mathrm{Pd}(111)$ surface, which is consistent with Lunsford's reports that almost no $\mathrm{H}_{2} \mathrm{O}_{2}$ was formed without the presence of additives. ${ }^{63}$

3.2.2 Reactivity on the $\mathrm{PdO}(101)$ surface. In view of the discussion on $\mathrm{O}_{2}$ and $\mathrm{H}_{2}$ adsorption of the $\mathrm{PdO}(101)$ surface, it follows that the preferential binding will be on the $\mathrm{Pd}_{\text {cus }}$ sites. Although the dissociation of $\mathrm{H}_{2}$ may be feasible, it will require a barrier of $0.38 \mathrm{eV}$. Therefore, we only consider molecularly adsorbed $\mathrm{O}_{2}$ and $\mathrm{H}_{2}$ on the $\mathrm{Pd}_{\text {cus }}$ sites. The reaction of $\mathrm{O}_{2}$ and $\mathrm{H}_{2}$ on the $\mathrm{PdO}(101)$ surface is displayed in Figure 4. As can be seen, the formation of the $\mathrm{OOH}$ species has a negligible barrier (TS6) of only $0.03 \mathrm{eV}$, which is $0.65 \mathrm{eV}$ lower in energy than the one calculated for the $\operatorname{Pd}(111)$ surface. Therefore, the $\mathrm{PdO}(101)$ surface is more favorable for the formation of $\mathrm{OOH}$ species with respect to the $\operatorname{Pd}(111)$ surface. The reaction energy for this step is $-0.39 \mathrm{eV}$. The formed $\mathrm{OOH}$ species is preferentially located on the top site of $\mathrm{Pd}_{\text {cus }}$ on the $\mathrm{PdO}(101)$ surface with the hydroxyl group positioned over an adjacent bridge site and the $\mathrm{O}-\mathrm{H}$ bond pointing away from the surface (structure IM6 in Figure 4). For the subsequent formation of $\mathrm{H}_{2} \mathrm{O}_{2}$, we considered the participation of a second molecule of $\mathrm{H}_{2}$ on an adjacent $\mathrm{Pd}_{\text {cus }}$ site neighboring the non-hydrogenated oxygen atom. The energy barrier for the second hydrogen atom transfer is estimated to be $0.46 \mathrm{eV}$ via $\mathbf{T S}_{7}$, which is higher in energy than the one found for the $\mathrm{OOH}$ formation step. However, it is still o.o9 eV lower in energy than the analogous transition state found for the $\mathrm{Pd}(111)$ surface. Moreover, the released energy that accompanies the adsorption of $\mathrm{O}_{2}$ and $\mathrm{H}_{2}$ will compensate for the high energy barrier. For the decomposition of the $\mathrm{OOH}$ species into atomic oxygen and a hydroxyl radical, a barrier (TS8) of $1.33 \mathrm{eV}$ was determined. By contrast, on the $\mathrm{Pd}(111)$ the barrier was only $0.11 \mathrm{eV}$ ( $\mathrm{TS}_{3}$ in Figure 3). In the case of $\mathrm{OOH}$ decomposition in the presence of adsorbed $\mathrm{H}_{2}$, similar to the results on the $\operatorname{Pd}(111)$ surface, the break of $\mathrm{O}-\mathrm{O}$ bond and the formation of $\mathrm{H}_{2} \mathrm{O}$ happens simultaneously. The barrier for concerted $\mathrm{H}_{2}$ insertion into $\mathrm{OOH}$ via TS9 has a barrier of $1.40 \mathrm{eV}$, while a much 
lower value was obtained on a pure $\operatorname{Pd}(111)$ surface. These results indicate that $\mathrm{OOH}$ decomposition will not be favored on the $\mathrm{PdO}\left({ }_{101}\right)$ surface and $\mathrm{H}_{2} \mathrm{O}$ will be an unlikely product. Decomposition of $\mathrm{H}_{2} \mathrm{O}_{2}$ requires a barrier of $0.77 \mathrm{eV}$, which is well higher in energy than both the formation of $\mathrm{OOH}$ and $\mathrm{H}_{2} \mathrm{O}_{2}$ reactions. In summary, the main reaction leading to the production of $\mathrm{H}_{2} \mathrm{O}_{2}$ is the most favorable pathway on $\mathrm{PdO}(101)$ surface.

As mentioned above, the elementary steps for the formation of $\mathrm{H}_{2} \mathrm{O}_{2}$ involve the hydrogenation of $\mathrm{O}_{2}$ to yield the key intermediate $\mathrm{OOH}$, and the further hydrogenation of $\mathrm{OOH}$ to generate the product $\mathrm{H}_{2} \mathrm{O}_{2}$. A comparison of the $\mathrm{H}_{2} \mathrm{O}_{2}$ formation potential energy surfaces of the processes on either the $\mathrm{PdO}(101)$ or $\mathrm{Pd}(111)$ surface reveals that both steps proceed on the $\mathrm{PdO}(101)$ surface with lower energy barriers. These results implicate that the formation of $\mathrm{H}_{2} \mathrm{O}_{2}$ on a $\mathrm{PdO}(101)$ surface will be much easier than that on a $\mathrm{Pd}(111)$ surface. The main side reactions accompanying the generation of $\mathrm{H}_{2} \mathrm{O}_{2}$ refer to the breaking of the $\mathrm{O}-\mathrm{O}$ bond, i.e., the dissociation of $\mathrm{O}_{2}$, the decomposition of the key intermediate $\mathrm{OOH}$, and the decomposition of the main product $\mathrm{H}_{2} \mathrm{O}_{2}$. The barrier for the dissociation of $\mathrm{O}_{2}$ on the $\mathrm{Pd}(111)$ surface is $0.70 \mathrm{eV}$, which is competitive with its hydrogenation process ( 0.68 $\mathrm{eV}$ ). By contrast, the dissociative adsorption of oxygen on the $\mathrm{PdO}(101)$ surface is well higher in energy than the most stable adsorption state, so that the dissociation of $\mathrm{O}_{2}$ on the $\mathrm{PdO}(101)$ surface will be unlikely. Consequently, the $\mathrm{Pd}(111)$ and $\mathrm{PdO}(101)$ surfaces are fundamentally different and react with substrates to form different products. In the Discussion section we will analyze the differences between the surfaces in detail.

\section{Discussion}

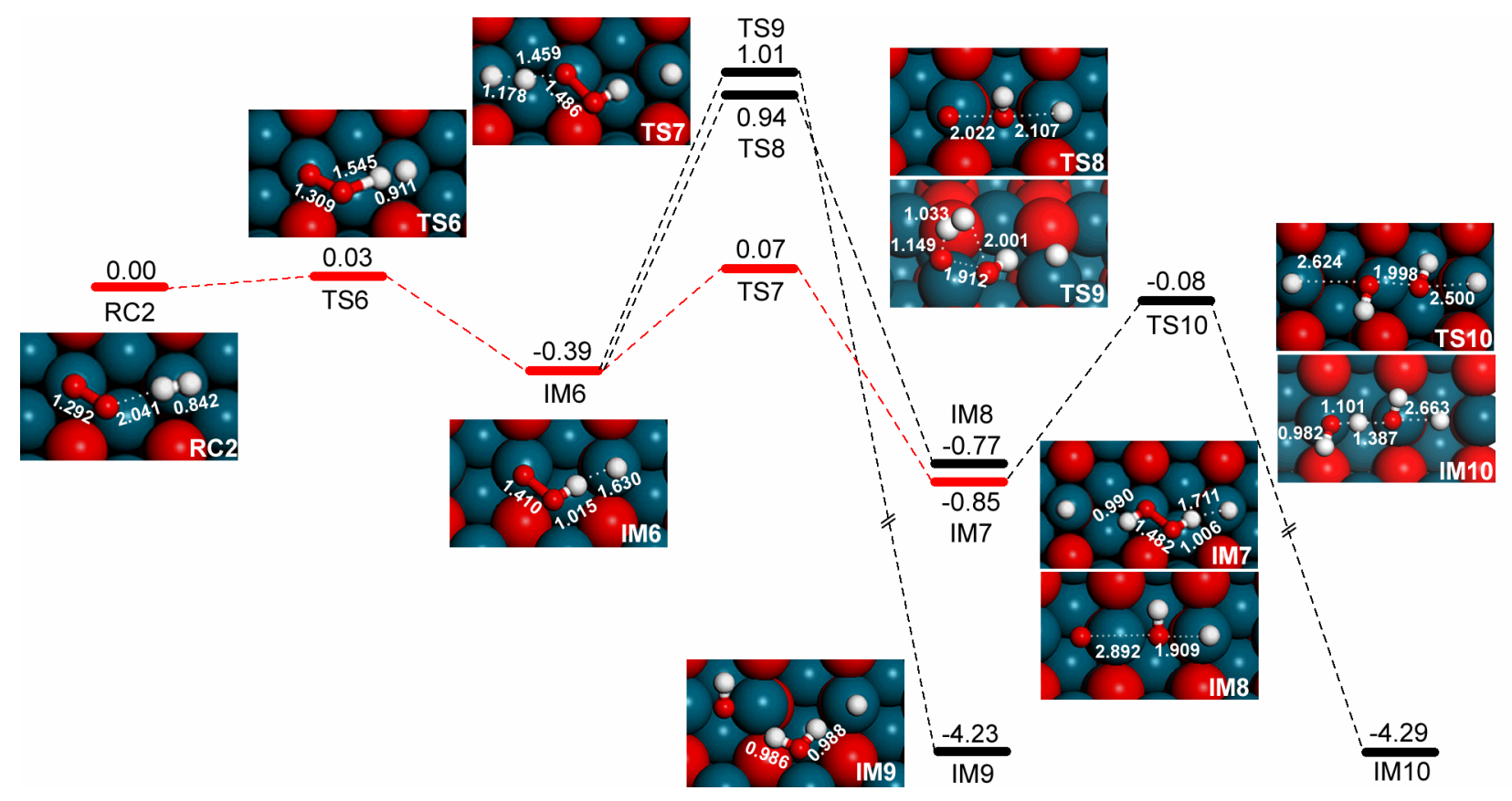

As shown in this work $\mathrm{Pd}(111)$ and $\mathrm{PdO}(101)$ surfaces efficiently react with $\mathrm{O}_{2}$ and $\mathrm{H}_{2}$ gas to form products; however, on the $\mathrm{Pd}(111)$ surface the reaction mostly gives water, whereas on the $\mathrm{PdO}(101)$ surface $\mathrm{H}_{2} \mathrm{O}_{2}$ is obtained in significant amounts. The formation of $\mathrm{H}_{2} \mathrm{O}_{2}$ was experimentally observed by Adzic and co-workers when catalysts with lower binding activity toward $\mathrm{O}_{2}$ were employed in oxygen reduction reaction, ${ }^{64}$ which is consistent with our computational results. The balance of the pathways leading to either $\mathrm{H}_{2} \mathrm{O}$ or $\mathrm{H}_{2} \mathrm{O}_{2}$ will depend on the adsorption of reactants $\left(\mathrm{O}_{2}\right.$ and $\left.\mathrm{H}_{2}\right)$, the cleavage energy of the $\mathrm{O}-\mathrm{O}$ bond in $\mathrm{O}_{2} / \mathrm{OOH} / \mathrm{H}_{2} \mathrm{O}_{2}$ and their binding strength to the metal surface.

Nørskov and co-workers proposed that the weighted center of the d-band $\left(\varepsilon_{\mathrm{d}}\right)$ (the average energy of the $\mathrm{d}$ electrons) of surface metal plays a vital role in determining the surface reactivity. ${ }^{65,66}$ Previous DFT and experimental studies established that the adsorption energies and reactivity of small adsorbents correlate well with the position of $\varepsilon_{\mathrm{d}}$ on metal surfaces. ${ }^{67,68}$ A surface with $\varepsilon_{\mathrm{d}}$ closer to the Fermi level generally gives a higher activity towards the binding of adsorbents. By contrast, a surface with $\varepsilon_{\mathrm{d}}$ shifting away from Fermi level often shows lower activity toward the adsorption of molecules. As such, we compared the $\varepsilon_{\mathrm{d}}$ value of $\mathrm{Pd}$ atoms on $\mathrm{Pd}(111)$ and $\mathrm{PdO}(101)$ surfaces. Our calculations give $\varepsilon_{\mathrm{d}}$ values of $2.01 \mathrm{eV}$ and $-2.84 \mathrm{eV}$ relative to Fermi level for $\mathrm{Pd}(111)$ and $\mathrm{PdO}(101)$, respectively. According to the d-band center theory, it is easier to infer that $\mathrm{PdO}(101)$ has lower activity toward the binding of reactant substrates and species formed during the reaction. This is in line with our calculated results that both $\mathrm{O}_{2}$ and $\mathrm{H}_{2}$ are less activated on $\mathrm{PdO}(101)$ in comparison with on $\mathrm{Pd}(111)$.

Similarly, we find that the $\mathrm{OOH}$ species on $\mathrm{PdO}(101)$ are

Figure 4. The energy profiles for the reaction of $\mathrm{O}_{2}$ with $\mathrm{H}_{2}$ on $\mathrm{PdO}(101)$ surface. The formation of $\mathrm{H}_{2} \mathrm{O}_{2}$ is labeled by red color. The energies are in $\mathrm{eV}$ unit. 
also less activated than on $\mathrm{Pd}(111)$. The $\mathrm{O}-\mathrm{O}$ bond distance of $\mathrm{OOH}$ is only $1.410 \AA$ (see IM6 in Figure 4) on $\mathrm{PdO}(101)$ while it is elongated to $1.516 \AA$ (see IM1 in Figure 3) on $\mathrm{Pd}(111)$. Moreover, the charge of $\mathrm{OOH}$ is -0.20 e on $\mathrm{PdO}(101)$ and -0.31 e on $\mathrm{Pd}(111)$, which further confirms a lesser activation of $\mathrm{OOH}$ on $\mathrm{PdO}(101)$. For the $\mathrm{H}$ atoms adsorbed on $\mathrm{Pd}(111)$ and $\mathrm{PdO}(101)$, we find $\mathrm{a}$ charge-transfer of -0.13 e and -0.10 e, respectively (see Tables $\mathrm{S}_{7}$ and $\mathrm{S}_{9}$ ). The present results suggest less electron transfer from the $\operatorname{PdO}(101)$ surface to the adsorbed $\mathrm{H}$ atoms as compared to the $\mathrm{Pd}(111)$ surface. This can be rationalized by a comparison of the work functions for the two surfaces. Values of $5.083 \mathrm{eV}$ for $\mathrm{PdO}(101)$ and $4.971 \mathrm{eV}$ for $\mathrm{Pd}(111)$ are found, hence the work function for $\mathrm{PdO}(101)$ is $0.112 \mathrm{eV}$ higher than that of $\mathrm{Pd}(111)$. Consequently, the escape of electrons from $\mathrm{PdO}(101)$ surface will more difficult than that from $\mathrm{Pd}(111)$ making $\mathrm{PdO}(101)$ less active than $\mathrm{Pd}(111)$. The change in work function is beneficial to inhibit the $\mathrm{O}-\mathrm{O}$ bond cleavage in $\mathrm{O}_{2} / \mathrm{OOH} / \mathrm{H}_{2} \mathrm{O}_{2}$ and results in the favorable formation of $\mathrm{H}_{2} \mathrm{O}_{2}$. Moreover, the electron transfer from the $\mathrm{Pd} / \mathrm{PdO}$ substrate to the anti-bonding orbitals of the $\mathrm{O}-\mathrm{O}$ species promotes the splitting of O-O bonds. The higher d-band energy corresponds to the stronger electron donating ability and thus the higher $\mathrm{O}-\mathrm{O}$ splitting activity. The higher d-band center of $\operatorname{Pd}(111)$ which denotes the higher d-band energy in comparison with $\mathrm{PdO}(101)$ confirms its high activity toward the splitting of $\mathrm{O}-\mathrm{O}$ bonds, which is adverse for the selective formation of $\mathrm{H}_{2} \mathrm{O}_{2}$. The passivation of $\mathrm{Pd}$ by oxygenation will weaken its activity toward $\mathrm{O}-\mathrm{O}$ species and thus facilitate the selective formation of $\mathrm{H}_{2} \mathrm{O}_{2}$.

In addition, the spatial arrangement of the $\mathrm{PdO}(101)$ surface is probably also relative to the lower activity towards the breaking of the $\mathrm{O}-\mathrm{O}$ bond. Our calculations reveal that the dissociation of $\mathrm{OOH}$ and $\mathrm{H}_{2} \mathrm{O}_{2}$ is easier on surfaces with hollow $\mathrm{Pd}$ sites, which are more prevalent on $\mathrm{Pd}(111)$ than $\mathrm{PdO}(101)$ surfaces. As a consequence, the $\mathrm{PdO}(101)$ surface gives selectivity towards $\mathrm{H}_{2} \mathrm{O}_{2}$ formation, while on $\operatorname{Pd}(111)$ the dioxygen bond breaks and water is the dominant product. Indeed, the high selectivity of $\mathrm{PdAu}$ alloy catalyst reported before is also attributed to the spatial arrangement of the surface atoms. ${ }^{31}$ Thus, DFT calculations showed that an active Pd atom surrounded by lesser active $\mathrm{Au}$ atoms gives enhanced reaction barriers for $\mathrm{O}-\mathrm{O}$ bond cleavage..$^{31}$ Furthermore, addition of hydrogen halides as additives were also shown to block the active site for $\mathrm{H}_{2} \mathrm{O}_{2}$ degradation and hence enhanced the selectivity for $\mathrm{H}_{2} \mathrm{O}_{2}$ product formation. ${ }^{20}$ However, we will emphasize that half of the $\mathrm{O}$ and $\mathrm{Pd}$ atoms on the $\mathrm{PdO}(101)$ surface are coordinatively unsaturated. $\mathrm{Pd}_{\text {cus }}$ possesses a coordination vacancy which plays a decisive role in oxidation chemistry. This unique structure of $\mathrm{Pd}_{\text {cus }}$ is only found in the oxidized Pd surfaces. Looking back at Figure 4, every elementary step takes place at these $\mathrm{Pd}_{\text {cus }}$ sites. Previous studies had also confirmed that $\mathrm{PdO}$ surface shows superior activity toward alkane oxidation, $\mathrm{CO}$ oxidation and methanol oxidation. ${ }^{44}$ Hence, it is reasonable to infer that the oxidation state instead of other factors in $\mathrm{PdO}(101)$, e.g., steric hindrance, plays a key role in improving its $\mathrm{H}_{2} \mathrm{O}_{2}$ selectivity.

To gain further insight into the mechanistic details of the reaction of $\mathrm{O}_{2}$ and $\mathrm{H}_{2}$ on $\mathrm{Pd}(111)$ and $\mathrm{PdO}(101)$ surfaces, we calculated thermochemical cycles for substrate $\left(\mathrm{O}_{2}\right.$ and $\mathrm{H}_{2}$ ) binding, their dissociation into bound-atoms and their coupling into products. Figure 5 displays calculated energetics for $\mathrm{O}_{2}$ and $\mathrm{H}_{2}$ binding to either $\mathrm{Pd}(111)$ and $\operatorname{PdO}(101)$. In all cases $\mathrm{O}_{2}$ and $\mathrm{H}_{2}$ bind with high exothermicity to the metal surfaces and hence are strongly bound. Subsequently, we calculated the dissociation of $\mathrm{O}_{2}$ on the metal surfaces. On the $\mathrm{Pd}(111)$ surface the $\mathrm{O}_{2}$ dissociation is exothermic with $258.2 \mathrm{~kJ}$ $\mathrm{mol}^{-1}$; however, it is endothermic by $174.9 \mathrm{~kJ} \mathrm{~mol}^{-1}$ on the $\mathrm{PdO}(101)$ surface. Consequently, dioxygen on a $\mathrm{Pd}(111)$ surface will quickly decompose into atoms, whereas it will not decompose on the $\mathrm{PdO}(101)$ surface. The same is seen for $\mathrm{H}_{2}$ binding to these two surfaces, whereby the $\mathrm{Pd}(111)$ gives highly exothermic hydrogen splitting into atoms. On the other hand, $\mathrm{H}_{2}$ dissociation is endothermic by only $22.6 \mathrm{~kJ} \mathrm{~mol}^{-1}$ on the $\mathrm{PdO}(101)$ surface and hence may be feasible. Therefore, dioxygen and hydrogen binding to $\mathrm{Pd}(111)$ or $\mathrm{PdO}(101)$ will lead to completely different adsorption patterns. In particular, the $\mathrm{Pd}(111)$ will lead to quick decomposition of $\mathrm{O}_{2}$ and $\mathrm{H}_{2}$, which will not be the case on the $\mathrm{PdO}(101)$ surface.

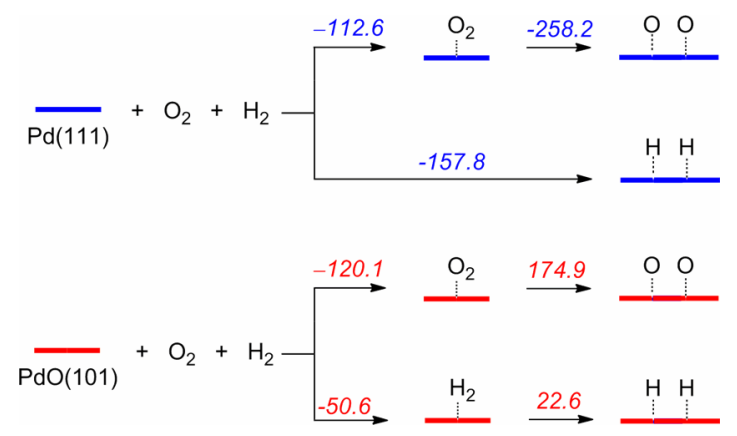

Figure 5. Binding energies (in $\mathrm{kJ} \mathrm{mol}^{-1}$ ) of $\mathrm{O}_{2}$ and $\mathrm{H}_{2}$ on $\mathrm{Pd}(111)$ (top) or $\mathrm{PdO}(101)$ (bottom) and the subsequent atomization.

Subsequently, we investigated the pathways leading to $\mathrm{H}_{2} \mathrm{O}_{2}$ and $\mathrm{H}_{2} \mathrm{O}$ formation on the $\mathrm{Pd}(111)$ and $\mathrm{PdO}(101)$ surfaces and the results are given in Figure 6. As mentioned above in Figure 5, on the $\operatorname{Pd}(111)$ surface both $\mathrm{O}_{2}$ and $\mathrm{H}_{2}$ will decompose into atoms. Thus, a surface bound $\mathrm{H}$-atom at the $\mathrm{Pd}(111)$ surface can react with an incoming $\mathrm{O}_{2}$ molecule to form $\mathrm{HOO}$ radicals. It is endothermic by $234.8 \mathrm{~kJ} \mathrm{~mol}^{-1}$. This $\mathrm{OOH}$ radical can then attack another surface-bound $\mathrm{H}$-atom to form $\mathrm{H}_{2} \mathrm{O}$ or $\mathrm{H}_{2} \mathrm{O}_{2}$. The former reaction is exothermic by $276.9 \mathrm{~kJ} \mathrm{~mol}^{-1}$, while the latter is endothermic by $95.2 \mathrm{~kJ} \mathrm{~mol}^{-1}$. Consequently, on the $\mathrm{Pd}(111)$ surface an $\mathrm{OOH}$ radical will react with surface bound $\mathrm{H}$-atoms to form $\mathrm{H}_{2} \mathrm{O}$ and no hydrogen peroxide should be formed through this pathway. These thermochemical values of isolated species are in line with the full reaction mechanism reported above in Figure 3. 


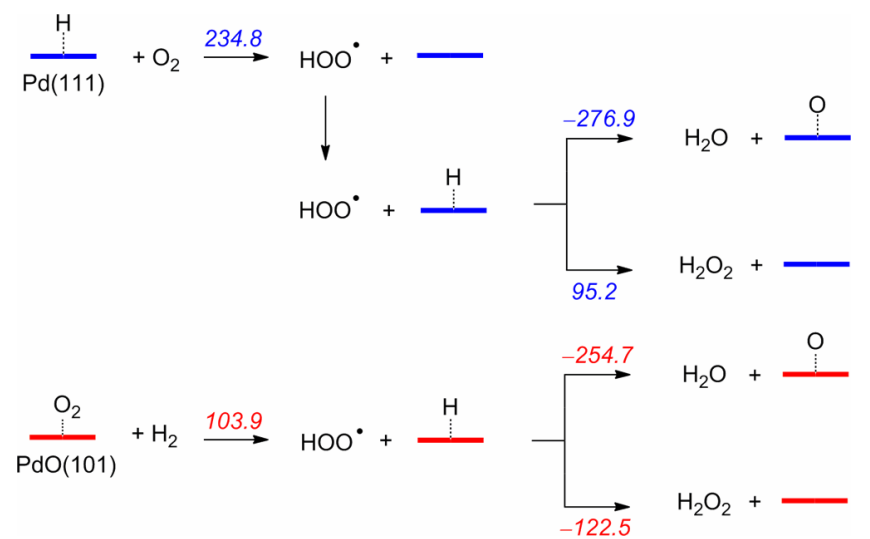

Figure 6. Thermochemical pathways for the synthesis of $\mathrm{H}_{2} \mathrm{O}$ and $\mathrm{H}_{2} \mathrm{O}_{2}$ from $\mathrm{O}_{2}$ and $\mathrm{H}_{2}$ on $\mathrm{Pd}(111)$ (top) and $\mathrm{PdO}(101$ ) surfaces. Reaction energies are given in $\mathrm{kJ} \mathrm{mol}^{-1}$.

Next, the formation of $\mathrm{H}_{2} \mathrm{O}$ and $\mathrm{H}_{2} \mathrm{O}_{2}$ on the $\mathrm{PdO}(101)$ surfaces was investigated. On this surface, dioxygen will not dissociate and will be present as Pd-superoxo form. Thus in a reaction with free $\mathrm{H}_{2}$ products $\mathrm{OOH}$ and surface bound $\mathrm{H}$-atoms in an endothermic reaction step. However, it is much less energetically demanding by 130.9 $\mathrm{kJ} \mathrm{mol}^{-1}$ than those on $\mathrm{Pd}(111)$. In the following step this pair splits into $\mathrm{H}_{2} \mathrm{O}$ and surface bound oxygen-atoms with an exothermicity of $254.7 \mathrm{~kJ} \mathrm{~mol}^{-1}$ or alternatively pair up to form hydrogen peroxide with an exothermicity of $\mathbf{1 2 2 . 5}$ $\mathrm{kJ} \mathrm{mol}^{-1}$. These thermochemical cycles are consistent with the DFT studies reported above, and indicate the formation of $\mathrm{H}_{2} \mathrm{O}$ on $\mathrm{PdO}$ is still the thermodynamically more favorable process than $\mathrm{H}_{2} \mathrm{O}_{2}$. However, it needs to conquer a much higher barrier $(1.40 \mathrm{eV})$ compared with $\mathrm{H}_{2} \mathrm{O}_{2}(0.46 \mathrm{eV})$. Therefore, $\mathrm{H}_{2} \mathrm{O}$ formation on $\mathrm{PdO}$ is kinetically unfavorable. As such, on the $\mathrm{PdO}(101)$ surface we predict dominant hydrogen peroxide products and lesser amount of water.

The difference between the $\operatorname{Pd}(111)$ and $\mathrm{Pd}(101)$ surfaces in $\mathrm{H}_{2} \mathrm{O}_{2}$ synthesis can be easily understood from a comparison of Figures 5 and 6 . HOO reacts with a surface-bound $\mathrm{H}$-atom by $\mathrm{H}$-atom abstraction. However, in the case of $\mathrm{Pd}(111)$ the binding energy of $\mathrm{H}$-atoms is considerably stronger than for the $\mathrm{PdO}(101)$ surface. Thus, $\mathrm{H}_{2}$ easily dissociates into surface-bound $\mathrm{H}$-atoms on $\operatorname{Pd}(111)$ and hence are strongly bound to the surface. By contrast, the reaction is endothermic on the $\mathrm{PdO}(101)$ surface. Then, the reaction of $\mathrm{HOO}$ with a surface-bound $\mathrm{H}$-atom (Figure 6) will require the cleavage of a very strong Pd-H bond on the $\mathrm{Pd}(111)$ surface to form $\mathrm{H}_{2} \mathrm{O}_{2}$. On the other hand, $\mathrm{HOO}$ can react with a surface-bound $\mathrm{H}$-atom to form $\mathrm{H}_{2} \mathrm{O}$ and form a stronger surface-bound O-atom.

It is worth to note that many factors can affect the oxidation state of Pd beyond oxygenation. Hutchings and co-workers ${ }^{23}$ reported that predominant $\mathrm{Pd}^{2+}$ species can be obtained after calcination of PdAu catalysts supported on the acid pre-treated carbon. However, on the acid untreated supports, the catalysts exhibit both $\mathrm{Pd}^{2+}$ and
$\mathrm{Pd}^{\circ}$. With different electronegativity, alloying is another method to modify the oxidation state of $\mathrm{Pd} .^{32}$ The heat treatment procedure with different atmosphere $\left(\mathrm{H}_{2}, \mathrm{O}_{2}\right.$ or air) can also change the oxidation state. With appropriate oxidation-reduction-oxidation heat treatment cycle, $\mathrm{Pd}^{2+}$ is confirmed as the predominant surface species for $\mathrm{PdSn}$ catalysts. These $\mathrm{Pd}^{2+}$ species was found play important roles for the selective generation of $\mathrm{H}_{2} \mathrm{O}_{2}$. However, the anion associated with $\mathrm{Pd}^{2+}$ is not clear. Usually, the catalysts used for the direct synthesis of $\mathrm{H}_{2} \mathrm{O}_{2}$ were calcined in air at the last preparation step. Moreover, the synthesis of $\mathrm{H}_{2} \mathrm{O}_{2}$ is performed in excess $\mathrm{O}_{2}$. XRD verified the formation of PdO. ${ }^{69}$ Thus, PdO may be one of the important oxidized forms of Pd. Recently, employing operando X-ray absorption spectroscopy (XAS) and online flow injection analysis, Selinsek and co-workers observed that $\mathrm{H}_{2}$ can dissolve in Pd resulting in the $\mathrm{PdH}_{\mathrm{x}}$ formation..$^{70}$ The added mineral acids combined with halides $\left(\mathrm{X}^{-}\right)$can oxidize Pd by dissolving nanoparticles..$^{56,71}$ Thus, the oxidized $\mathrm{Pd}$ may also exhibit as $\mathrm{PdH}_{\mathrm{x}}, \mathrm{PdX}^{-}$or else. ${ }^{10}$ All these oxidized $\mathrm{Pd}$ may contribute to the improvement of the $\mathrm{H}_{2} \mathrm{O}_{2}$ selectivity with new mechanistic features. Additionally, the effect of the coverage species on catalyst surface, such as the adsorbed $\mathrm{X}^{-}$, toward the selectivity of $\mathrm{H}_{2} \mathrm{O}_{2}$ is not well understood. All these issues will be further investigated in our future work.

Finally, a point should be made regarding the change of palladium into a different oxidation state. Thus, for iron containing monoxygenases, such as the cytochromes $\mathrm{P}_{450}$, molecular oxygen on an iron-heme center is selectively converted to water and a high-valent iron(IV)-oxo heme cation radical species. ${ }^{72-74}$ However, by selective protonation and reduction, an uncoupling reaction leading to hydrogen peroxide becomes available. This pathway is energetically unfavorable over the water formation pathway, ${ }^{75}$ similar to what is seen here for the $\mathrm{Pd}(111)$ vs $\mathrm{PdO}(101)$ system. By affecting the kinetics of the proton transfer, it was shown that the uncoupling reaction could become kinetically feasible. ${ }^{75}$ The same applies to the palladium systems described here. Furthermore, modeling of the $\mathrm{P} 450$ reactivity patterns showed that oxygen atom transfer is faster for the iron(IV)-oxo heme cation radical species than its one-electron reduced species, ${ }^{74,76}$ which is in support of the calculations reported here that efficient $\mathrm{H}_{2} \mathrm{O}_{2}$ formation is achieved through the oxidized form of the catalyst.

\section{Conclusion}

In conclusion, we studied the reaction of $\mathrm{O}_{2}$ and $\mathrm{H}_{2}$ gas on $\mathrm{Pd}(111)$ and $\mathrm{PdO}(101)$ surfaces using density functional theory methods. We obtain completely different reactivity patterns on the two surfaces, whereby the reaction on the $\mathrm{Pd}(111)$ surface leads to the formation of $\mathrm{H}_{2} \mathrm{O}$ products, whereas on the $\mathrm{PdO}(101)$ surface $\mathrm{H}_{2} \mathrm{O}_{2}$ is the dominant product. Furthermore, not only the activity toward the $\mathrm{H}_{2} \mathrm{O}_{2}$ production is higher but this pathway also shows much lower activity toward the undesirable side reactions, 
such as the dissociation of $\mathrm{O}_{2}$, and $\mathrm{OOH}$ and $\mathrm{H}_{2} \mathrm{O}_{2}$ products. This indicates that $\mathrm{PdO}(101)$ has higher activity and selectivity toward $\mathrm{H}_{2} \mathrm{O}_{2}$ as compared to $\mathrm{Pd}(111)$. We attribute this high performance of $\mathrm{PdO}(101)$ to its special electronic and geometrical structures. The down-shift of $\varepsilon_{\mathrm{d}}$ of $\mathrm{Pd}$ atoms in $\mathrm{PdO}(101)$ results in their weak interaction with binding adsorbents (whether $\mathrm{O}_{2}, \mathrm{H}_{2}$, $\mathrm{OOH}$, or $\mathrm{H}_{2} \mathrm{O}_{2}$ ), and further suppresses these adsorbents from dissociation and promotes the formation of hydrogen peroxide. The special geometrical structures isolate unsaturated Pd atoms as arrays and thus block the $\mathrm{O}-\mathrm{O}$ bond break process. Additionally, the high performance of $\mathrm{PdO}(101)$ could also be understood by thermodynamical differences of the $\operatorname{Pd}(111)$ and $\operatorname{Pd}(101)$ surfaces toward the binding of reaction substrates and the pathways for the synthesis of $\mathrm{H}_{2} \mathrm{O}$ and $\mathrm{H}_{2} \mathrm{O}_{2}$. The present results provide new insights into the active oxidation state of palladium for the direct synthesis of $\mathrm{H}_{2} \mathrm{O}_{2}$ from $\mathrm{H}_{2}$ and $\mathrm{O}_{2}$ and have more implications for the catalyst design.

\section{ASSOCIATED CONTENT}

Supporting Information. Supporting Information containing detailed absolute and relative energies as well as geometric data and Cartesian coordinates are given and is available free of charge on the ACS Publications website at DOI: 10.1021/jacs.

\section{AUTHOR INFORMATION}

\section{Corresponding Author}

*sam.devisser@manchester.ac.uk

*wangyong@licp.cas.cn

\section{Author Contributions}

The manuscript was written through contributions of all authors.

\section{ACKNOWLEDGMENT}

The authors acknowledge the financial support received from the National Natural Science Foundation of China (Project No. 21873052, 21173211, 21203218 and 21633013) and the open fund of the State Key Laboratory of Molecular Reaction Dynamics. The authors also gratefully acknowledge the computing resources and time made available by the Supercomputing Center of Cold and Arid Region Environment and the Engineering Research Institute of the Chinese Academy of Sciences.

\section{REFERENCES}

(1) Ciriminna, R.; Albanese, L.; Meneguzzo, F.; Pagliaro, M. Hydrogen Peroxide: A Key Chemical for Today's Sustainable Development. ChemSusChem 2o16, 9, 3374.

(2) Transparency Market Research, Hydrogen Peroxide Market for Paper \& Pulp, Chemical, Wastewater Treatment, Mining, and Other End-Users, Global Industry Analysis, Size, Share, Growth, Trends and Forecast 2015 - 2023, Albany, 2015.

(3)Riedl, H.-J.; Pfleiderer, G. Production of hydrogen peroxide. US 21585251939.

(4)Campos-Martin, J. M.; Blanco-Brieva, G.; Fierro, J. L. Hydrogen peroxide synthesis: An outlook beyond the anthraquinone process. Angew. Chem. Int. Ed. 2006, 45, 6962.
(5) Edwards, J. K.; Hutchings, G. J. Palladium and gold-palladium catalysts for the direct synthesis of hydrogen peroxide. Angew. Chem. Int. Ed. 2008, 47, 9192.

(6) Edwards, J. K.; Solsona, B.; Ntainjua, E. N.; Carley, A. F.; Herzing, A. A.; Kiely, C. J.; Hutchings, G. J. Switching off hydrogen peroxide hydrogenation in the direct synthesis process. Science 2009, 323, 1037.

(7) Freakley, S. J.; He, Q.; Harrhy, J. H.; Lu, L.; Crole, D. A.; Morgan, D. J.; Ntainjua, E. N.; Edwards, J. K.; Carley, A. F.; Borisevich, A. Y.; Kiely, C. J.; Hutchings, G. J. Palladium-tin catalysts for the direct synthesis of $\mathrm{H}_{2} \mathrm{O}_{2}$ with high selectivity. Science 2016, 351, 965.

(8) Edwards, J. K.; Freakley, S. J.; Carley, A. F.; Kiely, C. J.; Hutchings, G. J. Strategies for designing supported gold-palladium bimetallic catalysts for the direct synthesis of hydrogen peroxide. Acc. Chem. Res. 2014, 47, 845.

(9) Wilson, N. M.; Flaherty, D. W. Mechanism for the direct synthesis of $\mathrm{H}_{2} \mathrm{O}_{2}$ on Pd clusters: heterolytic reaction pathways at the liquid-solid interface. J. Am. Chem. Soc. 2016, 138, 574.

(10) Flaherty, D. W. Direct synthesis of $\mathrm{H}_{2} \mathrm{O}_{2}$ from $\mathrm{H}_{2}$ and $\mathrm{O}_{2}$ on Pd catalysts: current understanding, outstanding questions, and research needs. ACS Catal. 2018, 8, 1520.

(11)Wilson, N. M.; Pan, Y.-T.; Shao, Y.-T.; Zuo, J.-M.; Yang, H.; Flaherty, D. W. Direct synthesis of $\mathrm{H}_{2} \mathrm{O}_{2}$ on AgPt octahedra: The importance of Ag-Pt coordination for high $\mathrm{H}_{2} \mathrm{O}_{2}$ selectivity. ACS Catal. 2018, 8, 2880.

(12) García-Serna, J.; Moreno, T.; Biasi, P.; Cocero, M. J.; Mikkola, J.-P.; Salmi, T. O. Engineering in direct synthesis of hydrogen peroxide: targets, reactors and guidelines for operational conditions. Green Chem. 2014, 16, 2320.

(13) Yi, Y.; Wang, L.; Li, G.; Guo, H. A review on research progress in the direct synthesis of hydrogen peroxide from hydrogen and oxygen: noble-metal catalytic method, fuel-cell method and plasma method. Catal. Sci. Technol. 2016, 6, 1593.

(14) Henkel, H.; Weber, W. Manufacture of hydrogen peroxide. US 11087521914.

(15) Deguchi, T.; Iwamoto, M. Reaction mechanism of direct $\mathrm{H}_{2} \mathrm{O}_{2}$ synthesis from $\mathrm{H}_{2}$ and $\mathrm{O}_{2}$ over $\mathrm{Pd} / \mathrm{C}$ catalyst in water with $\mathrm{H}^{+}$and $\mathrm{Br}^{-}$ions. J. Catal. 2011, 280, 239.

(16) Choudhary, V. R.; Ingole, Y. V.; Samanta, C.; Jana, P. Direct oxidation of hydrogen to hydrogen peroxide over Pd (or $\mathrm{PdO}) / \mathrm{Al}_{2} \mathrm{O}_{3}$ in aqueous reaction medium: influence of different acids and halide anions in reaction medium on formation and destruction of $\mathrm{H}_{2} \mathrm{O}_{2}$. Ind. Eng. Chem. Res. 2007, 46, 8566 .

(17) Ntainjua, N. E.; Piccinini, M.; Pritchard, J. C.; Edwards, J. K.; Carley, A. F.; Moulijn, J. A.; Hutchings, G. J. Effect of halide and acid additives on the direct synthesis of hydrogen peroxide using supported gold-palladium catalysts. ChemSusChem 2009, 2, 575.

(18) Choudhary, V.; Samanta, C. Role of chloride or bromide anions and protons for promoting the selective oxidation of $\mathrm{H}_{2}$ by $\mathrm{O}_{2}$ to $\mathrm{H}_{2} \mathrm{O}_{2}$ over supported Pd catalysts in an aqueous medium. J. Catal. 2006, 238, 28.

(19) Centomo, P.; Meneghini, C.; Sterchele, S.; Trapananti, A.; Aquilanti, G.; Zecca, M. EXAFS in situ: The effect of bromide on Pd during the catalytic direct synthesis of hydrogen peroxide. Catal. Today 2015, 248, 138.

(20) Deguchi, T.; Iwamoto, M. Catalytic properties of surface sites on Pd clusters for direct $\mathrm{H}_{2} \mathrm{O}_{2}$ synthesis from $\mathrm{H}_{2}$ and $\mathrm{O}_{2}$ : A DFT study. J. Phys. Chem. C 2013, 117, 18540.

(21) Edwards, J. K.; Ntainjua, E. N. ; Carley, A. F.; Herzing, A. A.; Kiely, C. J.; Hutchings, G. J. Direct synthesis of $\mathrm{H}_{2} \mathrm{O}_{2}$ from $\mathrm{H}_{2}$ and $\mathrm{O}_{2}$ over gold, palladium, and gold-palladium catalysts supported on acid-pretreated $\mathrm{TiO}_{2}$. Angew. Chem. Int. Ed. 2oog, 48,8512 .

(22) Rankin, R. B.; Greeley, J. Trends in selective hydrogen 
peroxide production on transition metal surfaces from first principles. ACS Catal. 2012, 2, 2664.

(23) Edwards, J. K.; Pritchard, J.; Piccinini, M.; Shaw, G.; He, Q.; Carley, A. F.; Kiely, C. J.; Hutchings, G. J. The effect of heat treatment on the performance and structure of carbon-supported $\mathrm{Au}-\mathrm{Pd}$ catalysts for the direct synthesis of hydrogen peroxide. J. Catal. 2012, 292, 227.

(24) Choudhary, V. R.; Gaikwad, A. G.; Sansare, S. D. Activation of supported Pd metal catalysts for selective oxidation of hydrogen to hydrogen peroxide. Catal. Lett. 2002, 83, 235.

(25) Choudhary, V. R.; Sansare, S. D.; Gaikwad, A. G. Direct oxidation of $\mathrm{H}_{2}$ to $\mathrm{H}_{2} \mathrm{O}_{2}$ and decomposition of $\mathrm{H}_{2} \mathrm{O}_{2}$ over oxidized and reduced Pd-containing zeolite catalysts in acidic medium. Catal. Lett. 2002, 84, 81.

(26) Choudhary, V. R.; Samanta, C.; Choudhary, T. V. Direct oxidation of $\mathrm{H}_{2}$ to $\mathrm{H}_{2} \mathrm{O}_{2}$ over Pd-based catalysts: Influence of oxidation state, support and metal additives. Appl. Catal., A 2006, 308, 128.

(27) Melada, S.; Rioda, R.; Menegazzo, F.; Pinna, F.; Strukul, G. Direct synthesis of hydrogen peroxide on zirconia-supported catalysts under mild conditions. J. Catal. 2006, 239, 422.

(28) Menegazzo, F.; Manzoli, M.; Signoretto, M.; Pinna, F.; Strukul, G. $\mathrm{H}_{2} \mathrm{O}_{2}$ direct synthesis under mild conditions on $\mathrm{Pd}-$ Au samples: Effect of the morphology and of the composition of the metallic phase. Catal. Today 2015, 248, 18.

(29) Ouyang, L.; Tian, P.-f.; Da, G.-j.; Xu, X.-C.; Ao, C.; Chen, T.-y.; Si, R.; Xu, J.; Han, Y.-F. The origin of active sites for direct synthesis of $\mathrm{H}_{2} \mathrm{O}_{2}$ on $\mathrm{Pd} / \mathrm{TiO}_{2}$ catalysts: Interfaces of $\mathrm{Pd}$ and PdO domains. J. Catal. 2015, 321, 70.

(30) Gudarzi, D.; Ratchananusorn, W.; Turunen, I.; Salmi, T.; Heinonen, M. Preparation and study of $\mathrm{Pd}$ catalysts supported on activated carbon cloth (ACC) for direct synthesis of $\mathrm{H}_{2} \mathrm{O}_{2}$ from $\mathrm{H}_{2}$ and $\mathrm{O}_{2}$. Top. Catal. 2013, 56, 527.

(31) Ham, H. C.; Hwang, G. S.; Han, J.; Nam, S. W.; Lim, T. $\mathrm{H}$. On the role of Pd ensembles in selective $\mathrm{H}_{2} \mathrm{O}_{2}$ formation on PdAu alloys. J. Phys. Chem. C 2009, 113, 12943.

(32) Beletskaya, A. V.; Pichugina, D. A.; Shestakov, A. F.; Kuz'menko, N. E. Formation of $\mathrm{H}_{2} \mathrm{O}_{2}$ on $\mathrm{Au}_{20}$ and $\mathrm{Au}_{19} \mathrm{Pd}$ clusters: Understanding the structure effect on the atomic level. J. Phys. Chem. A 2013, 117, 6817 .

(33) Li, J.; Staykov, A.; Ishihara, T.; Yoshizawa, K. Theoretical study of the decomposition and hydrogenation of $\mathrm{H}_{2} \mathrm{O}_{2}$ on Pd and Au@Pd surfaces: Understanding toward high selectivity of $\mathrm{H}_{2} \mathrm{O}_{2}$ synthesis. J. Phys. Chem. C 2011, 115, 7392.

(34) Li, J.; Ishihara, T.; Yoshizawa, K. Theoretical revisit of the direct synthesis of $\mathrm{H}_{2} \mathrm{O}_{2}$ on Pd and Au@Pd surfaces: A comprehensive mechanistic study. J. Phys. Chem. C 2011, 115, 25359 .

(35) Wells Jr., D. H.; Delgass, W. N.; Thomson, K. T. Thomson Formation of hydrogen peroxide from $\mathrm{H}_{2}$ and $\mathrm{O}_{2}$ over a neutral gold trimer: a DFT study. J. Catal. 2004, 225, 69.

(36) Wang, F.; Zhang, D.; Sun, H.; Ding, Y. Theoretical investigation of the formation of hydrogen peroxide from $\mathrm{H}_{2}$ and $\mathrm{O}_{2}$ over anionic gold clusters $\mathrm{Au}_{\mathrm{n}}{ }^{-}(\mathrm{n}=1-4)$. J. Phys. Chem. $\mathrm{C}$ 2007, 111, 11590.

(37) Njegic, B.; Gordon, M. S. Reaction mechanism of the direct gas phase synthesis of $\mathrm{H}_{2} \mathrm{O}_{2}$ catalyzed by $\mathrm{Au}_{3}$. J. Chem. Phys, 2008, 129, 124705.

(38) Kacprzak, K. A.; Akola, J.; Hakkinen, H. First-principles simulations of hydrogen peroxide formation catalyzed by small neutral gold clusters. Phys. Chem. Chem. Phys. 2009, 11, 6359.

(39) Grabow, L. C.; Hvolbæk, B.; Falsig, H.; Nørskov, J. K. Search directions for direct $\mathrm{H}_{2} \mathrm{O}_{2}$ synthesis catalysts starting from $\mathrm{Au}_{12}$ nanoclusters. Top. Catal. 2012, 55, 336.
(40) Yang, H. F.; Xie, P. Y.; Yu, H. Y.; Li, X. N.; Wang, J. G. The effect of CNTs on structures and catalytic properties of AuPd clusters for $\mathrm{H}_{2} \mathrm{O}_{2}$ synthesis. Phys. Chem. Chem. Phys. 2012, 14,16654 .

(41) Plauck, A.; Stangland, E. E.; Dumesic, J. A.; Mavrikakis, M. Active sites and mechanisms for $\mathrm{H}_{2} \mathrm{O}_{2}$ decomposition over Pd catalysts. Proc. Natl. Acad. Sci. USA 2016, 113, E1973.

(42) Tian, P.; Ouyang, L.; Xu, X.; Xu, J.; Han, Y. F. Density functional theory study of direct synthesis of $\mathrm{H}_{2} \mathrm{O}_{2}$ from $\mathrm{H}_{2}$ and $\mathrm{O}_{2}$ on $\mathrm{Pd}(111), \mathrm{Pd}(100)$, and $\mathrm{Pd}(110)$ surfaces. Chinese J. Catal. 2013, 34, 1002.

(43) Farberow, C. A.; Godinez-Garcia, A.; Peng, G.; Perez-Robles, J. F.; Solorza-Feria, O.; Mavrikakis, M. Mechanistic studies of oxygen reduction by hydrogen on $\operatorname{PdAg}(110)$. ACS Catal. 2013, 3, 1622.

(44) Weaver, J. F. Surface chemistry of late transition metal oxides. Chem. Rev. 2013, 113, 4164.

(45) Rogal, J.; Reuter, K.; Scheffler, M. Thermodynamic stability of PdO surfaces. Phys. Rev. B 2004, 69, 075421.

(46) Vanderbilt, D. Soft self-consistent pseudopotentials in a generalized eigenvalue formalism. Phys. Rev. B 1990, 41, 7892 .

(47) Perdew, J. P.; Burke, K.; Ernzerhof, M. Generalized gradient approximation made simple. Phys. Rev. Lett. 1996, 77, 3865 .

(48) Milman, V.; Winkler, B.; White, J. A.; Pickard, C. J.; Payne, M. C.; Akhmatskaya, E. V.; Nobes, R. H. Electronic structure, properties, and phase stability of inorganic crystals: A pseudopotential plane-wave study. Int. J. Quantum Chem. 2ooo, 77,895 .

(49) Li, X.; Sun, X.; Xu, X.; Liu, W.; Peng, H.; Fang, X.; Wang, H.; Wang, X. CO oxidation on PdO catalysts with perfect and defective rutile- $\mathrm{TiO}_{2}$ as supports: Elucidating the role of oxygen vacancy in support by DFT calculations. Appl. Surf. Sci. 2017, 401, 49.

(50) Hinojosa, J. A.; Antony, A.; Hakanoglu, C.; Asthagiri, A.; Weaver, J. F. Adsorption of $\mathrm{CO}_{2}$ on a $\mathrm{PdO}(101)$ Thin Film. J. Phys. Chem. C 2012, 116, 3007.

(51) Chin, Y. H.; Buda, C.; Neurock, M.; Iglesia, E. Consequences of metal-oxide interconversion for $\mathrm{C}-\mathrm{H}$ bond activation during $\mathrm{CH}_{4}$ reactions on Pd catalysts. J. Am. Chem. Soc. 2013, 135, 15425

(52) Henkelman, G.; Arnaldsson, A.; Jónsson, H. A fast and robust algorithm for Bader decomposition of charge density. Comput. Mater. Sci. 2006, 36, 354.

(53) Tang, W.; Sanville, E.; Henkelman, G. A grid-based Bader analysis algorithm without lattice bias. J. Phys.: Condens. Matter 2009, 21, 084204.

(54) Lamber, R.; Wetjen, S.; Jaeger, N. I. Size dependence of the lattice parameter of small palladium particles. Phys. Rev. B 1995, 51, 10968.

(55) Rogers, D.; Shannon, R.; Gillson, J. Crystal growth and semiconductivity of palladium oxide. J. Solid State Chem. 1971, 3, 314 .

(56) Lunsford, J. H. The direct formation of $\mathrm{H}_{2} \mathrm{O}_{2}$ from $\mathrm{H}_{2}$ and $\mathrm{O}_{2}$ over palladium catalysts. J. Catal. 2003, 216, 455.

(57) Brazzolotto, D.; Cantú Reinhard, F. G.; Smith-Jones, J.; Retegan, M.; Amidani, L.; Faponle, A. S.; Ray, K.; Philouze, C.; de Visser, S. P.; Gennari, M.; Duboc, C. A high-valent non-heme $\mu$-oxo manganese(IV) dimer generated from a thiolate-bound manganese(II) complex and dioxygen. Angew. Chem. Int. Ed. 2017, 56, 8211.

(58) Cantú Reinhard, F. G.; Barman, P.; Mukherjee, G.; Kumar, J.; Kumar, D.; Kumar, D.; Sastri, C. V.; de Visser, S. P. Keto-Enol tautomerization triggers an electrophilic aldehyde 
deformylation reaction by a nonheme manganese(III)-peroxo complex. J. Am. Chem. Soc. 2017, 139, 18328.

(59) Todorovic, R.; Meyer, R. J. A comparative density functional theory study of the direct synthesis of $\mathrm{H}_{2} \mathrm{O}_{2}$ on $\mathrm{Pd}, \mathrm{Pt}$ and Au surfaces. Catal. Today 2011, 160, 242.

(6o) Shen, X.; Liu, W.; Gao, X.; Lu, Z.; Wu, X.; Gao, X. Mechanisms of oxidase and superoxide dismutation-like activities of gold, silver, platinum, and palladium, and their alloys: A general way to the activation of molecular oxygen. J. Am. Chem. Soc. 2015, 137, 15882.

(61) Jose A. Hinojosa, J.; Kan, H. H.; Weaver, J. F. Molecular chemisorption of $\mathrm{O}_{2}$ on a $\mathrm{PdO}(101)$ thin film on $\mathrm{Pd}(111)$. J. Phys. Chem. C 2008, 112, 8324.

(62) Sivadinarayana, C.; Choudhary, T. V.; Daemen, L. L.; Eckert, J.; Goodman, D. W. The Nature of the surface species formed on $\mathrm{Au} / \mathrm{TiO}_{2}$ during the reaction of $\mathrm{H}_{2}$ and $\mathrm{O}_{2}$ : An inelastic neutron scattering study. J. Am. Chem. Soc. 2004, 126, 38.

(63) Liu, Q.; Lunsford, J. H. Controlling factors in the direct formation of $\mathrm{H}_{2} \mathrm{O}_{2}$ from $\mathrm{H}_{2}$ and $\mathrm{O}_{2}$ over a $\mathrm{Pd} / \mathrm{SiO}_{2}$ catalyst in ethanol. Appl. Catal., A 2006, 314, 94.

(64) Zhang, J.; Vukmirovic, M. B.; Xu, Y.; Mavrikakis, M.; Adzic, R. R. Controlling the catalytic activity of platinum-monolayer electrocatalysts for oxygen reduction with different substrates. Angew. Chem. Int. Ed. 2005, 44, 2132.

(65) Hammer, B.; Nørskov, J. K. In Advances in Catalysis; Academic Press: 2000; Vol. 45, p 71.

(66) Greeley, J.; Nørskov, J. K.; Mavrikakis, M. Electronic structure and catalysis on metal surfaces. Annu. Rev. Phys. Chem. 2002, 53, 319.

(67) Greeley, J.; Mavrikakis, M. Alloy catalysts designed from first principles. Nat. Mater. 2004, 3, 810.

(68) Xu, Y.; Ruban, A. V.; Mavrikakis, M. Adsorption and dissociation of $\mathrm{O}_{2}$ on Pt-Co and Pt-Fe Alloys. J. Am. Chem. Soc. 2004, 126, 4717.

(69) Samanta, C.; Choudhary, V. R. Direct oxidation of $\mathrm{H}_{2}$ to $\mathrm{H}_{2} \mathrm{O}_{2}$ over $\mathrm{Pd} / \mathrm{CeO}_{2}$ catalyst under ambient conditions: Influence of halide ions. Chem. Eng. J. 20o8, 136, 126.

(70) Selinsek, M.; Deschner, B. J.; Doronkin, D. E.; Sheppard, T. L.; Grunwaldt, J.-D.; Dittmeyer, R. Revealing the structure and mechanism of palladium during direct synthesis of hydrogen peroxide in continuous flow using operando spectroscopy. ACS Catal. 2018, 8, 2546.

(71) Chinta, S.; Lunsford, J. H. A mechanistic study of $\mathrm{H}_{2} \mathrm{O}_{2}$ and $\mathrm{H}_{2} \mathrm{O}$ formation from $\mathrm{H}_{2}$ and $\mathrm{O}_{2}$ catalyzed by palladium in an aqueous medium. J. Catal. 2004, 225, 249.

(72) Shaik, S.; Kumar, D.; de Visser, S. P.; Altun, A.; Thiel, $\mathrm{W}$. Theoretical perspective on the structure and mechanism of cytochrome P450 enzymes. Chem. Rev. 2005, 105, 2279.

(73) Li, D.; Wang, Y.; Han, K. Recent density functional theory model calculations of drug metabolism by cytochrome P45o. Coord. Chem. Rev. 2012, 1137.

(74) Li, X.-X.; Postils, V.; Sun, W.; Faponle, A. S.; Solà, M.; Wang, Y.; Nam, W.; de Visser, S. P. Reactivity patterns of (protonated) compound II and compound I of cytochrome P450: Which is the better oxidant? Chem. Eur. J. 2017, 23, 6406.

(75) Altarsha, M.; Benighaus, T.; Kumar, D.; Thiel, W. How is the reactivity of cytochrome $\mathrm{P}_{450} \mathrm{O}_{\text {cam }}$ affected by Thr252X mutation? A $\mathrm{QM} / \mathrm{MM}$ study for $\mathrm{X}=$ serine, valine, alanine, glycine. J. Am. Chem. Soc. 2009, 131, 4755.

(76) Postils, V.; Saint-André, M.; Timmins, A.; Li, X.-X.; Wang, Y.; Luis, J. M.; Solà, M.; de Visser, S. P. Quantum mechanics/molecular mechanics studies on the relative reactivities of Compound I and II in cytochrome P450 enzymes. Int. J. Mol. Sci. 2018, 19, 1974. 
Table of Contents Graphic

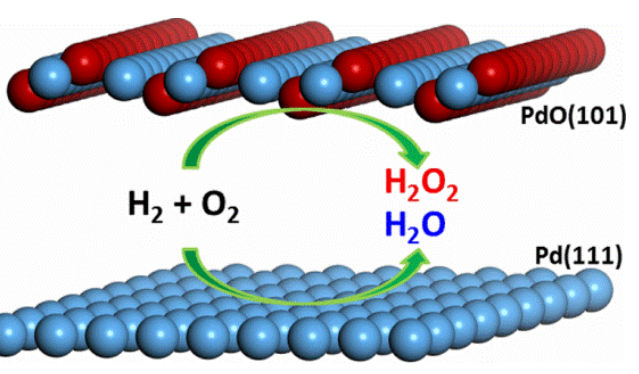

